\title{
Multiskilling in the Newsroom: De-skilling or Re-skilling of Journalistic Work?
}

\author{
Gunnar Nygren \\ Dept. of social sciences, Södertörn University \\ E-mail: gunnar.nygren@sh.se
}

\begin{abstract}
Multiskilling in a journalism context is not a case of "de-skilling" of the profession. There are problems related to the quality in newsrooms adapting multiskilling strategies, but in general multiskilling is more correctly defined as a re-skilling or an up-skilling. This is the conclusion from results of a survey of 1,500 journalists in Poland, Russia and Sweden, along with interviews with 60 journalists in these three countries. Multiskilling in journalism gives more room for creativity and more power to the individual journalist, according to those with experience of working as multi-reporters. It allows them more freedom to make their own decisions in their daily tasks, e.g., choosing subjects and stories. At the same time, from the perspective of the media company, multiskilling is a strategy to increase production in the newsrooms. But multiskilling has no direct correlation with downsized newsrooms: it is rather an industry norm for how to organize work in newsrooms of today. Multiskilling is also changing the journalistic culture, putting more focus on production and adapting content for different channels.
\end{abstract}

\section{Keywords:}

Multiskilling, journalistic work, cross-platform production, professional identity 


\section{Introduction}

The division of labour in media production has changed radically over the past 20 years. New technology has reduced the size of or eliminated professional groups connected to technical production (for example, pre-print processes in newspapers and editing in radio/TV). Multiskilling has been described in research as a way to increase productivity, i.e., to get more content produced with the same number or fewer journalists (Lee-Wright \& Philips, 2012). It has also been described as a de-skilling of journalism as a profession, as a part in a historical process to "naturalize the dominance of technology over journalism" (Örnebring, 2010). There are also more positive ways to describe multiskilling, for example as a way to strengthen the competence of journalists, giving them more room in production (Deuze, 2007). Research also shows many different ways to apply multiskilling in different types of media (Nygren, 2008; Nygren \& Zuiderveld, 2011).

A number of years have passed since digital tools were introduced into the editorial production in all media forms, and digital technology has now been normalized into daily activities. The purpose of this article is to show how journalists in three different kind of media systems perceive multiskilling, how digital tools are integrated into the daily work in newsrooms, and the increasing demands to not only handle the entire production process but also to produce for different platforms.

The essay is based on a survey given to 1,500 journalists in Poland, Russia and Sweden and then 60 interviews in the three countries. After a short review of previous research, the results are used for a discussion about de-skilling or reskilling of the journalistic profession in different media systems.

\section{Multiskilling in journalistic work}

The change present in journalistic work has been described by research as having the same patterns all over the western world - cross-platform production, deadlines 24/7, multiskilling and flexible news workers going in and out of production and a growing interactivity with the audience (Deuze, 2007; Mitchelstein \& Boczkowski, 2009; Lee Wright, Witschge \& Philips, 2012). Journalism has changed from producing products (articles and features) to being more of a process for producing news day and night without deadlines, a process where the content is developed in front of and in some kind of dialog with the audience (Karlsson, 2010).

This change is similar to other parts of industry in that the "third industrial revolution" gives more room for flexible production systems, flat organizations and multiskilled competences (Magnusson, 2006). The trend is that industry is moving away from "Tayloristic" specialization in work processes and instead moving towards a larger degree of employee flexibility. There is more work in 
groups and these groups are responsible for a larger part of the production as well as for the demand for a broad range of skills. Production is outsourced to lower the cost and make production flexible (Börnfelt, 2011).

There is no common definition in research for the notion of "multiskilling" (Lee-Wright \& Philips, 2012). On the basis of research on newsrooms in Sweden, two definitions of multiskilling can be made. These definitions are often, but not necessarily, connected (Nygren \& Zuiderveld, 2011):

- To handle the entire process: from gathering all kinds of material to producing, editing and (for radio/TV) delivering it to the audience. In TVproduction the term used is "video journalists" and refers to journalists doing all types of work that was previously done by specialists.

- To work for different platforms. This can be done at the same time gathering material and producing both for web and print, producing both still and live images or both radio and video. It can also be the ability to work for different platforms, but on separate occasions.

These new demands have met much resistance among journalists; a lack of education in the new tools and increasing demands on the amount of production has raised much criticism (Quinn, 2005, Mitchelstein \& Boczkowski, 2009, Quandt \& Singer, 2009 ). Many journalists view multiskilling as a means to increase production with fewer people at the media company. Large media organizations have been more cautious about introducing multiskilling using arguments based on quality, and others emphasize the cognitive limits on multitasking (Nygren \& Zuiderveld, 2011, Lee-Wright \& Philips, 2012).

Some surveys show that journalists think technical skills are much less important than basic journalistic skills such as writing, research and the ability to work independently (Opgehaffen, d'Haenens \& Corten, 2013). Still, the demands on technical skills are high in the daily work, and it is difficult for many journalists to find time for reflection and research during the work process. Also, a kind of polarization can be found between experienced journalists with high autonomy and young, flexible journalists doing more factory-like work (Örnebring, 2013, Ottosen \& Krumsvik, 2010).

Recent studies also find, however, that there is room for creative possibilities and a larger degree of autonomy in processes that have higher demands on multiskilling and multitasking. A study of commercial radio production shows that digital production systems can give producers more power in their daily work and promote creativity, although this is based on a common ideology in the company as well as polarization between "stars" and other temporarily employed workers in production (Stiernstedt, 2013). A study of commercial TV shows that the development of news production into a $24 / 7$ process in a digital environment is based to a large degree on autonomy for the employed. The culture of the media house is important in this and journalists become specialists in 
coordinating the various elements of the craft of the multiskilled profession (Konow Lund, 2013).

Research has discussed whether changes in media production can be regarded as a de-skilling or an up-skilling of the journalistic work (Örnebring, 2010; Stiernstedt, 2013). The notion of "de-skilling" has been used to describe the development of industrial labor during the 20th century, a period during which the craft of the worker was reduced by the division of labor. In journalism, this has been described in connection with "production journalists" in the UK, who mostly work with recycling content and adapting content to different platforms and are less occupied with traditional journalistic competences such as research and writing (Örnebring, 2010). While technological development gives new tools to journalists, there is a need for new competencies and new options for expression. In that sense, digital tools demand a "re-skilling" - to add new competencies to the older, more traditional competencies.

In journalism, technological development has often been used to explain changes in work. Technology in and of itself, and not the way work processes are organized, is used to explain how work is changing, but technology cannot explain everything. The social, economical and cultural practices in which journalism is embedded are what matters (Örnebring, 2010). If focus is shifted from technology to the concept of labor processes and notions such as de-skilling or re-skilling, it becomes possible to discuss how changing work (and digital tools) influences journalism as a process.

The purpose of this paper is to study experiences and attitudes towards the notion of "multiskilling" among journalists. The basic question is whether multiskilling means a de-skilling of journalistic competences or, on the contrary, if it can be regarded as a re-skilling or an up-skilling of journalism. Or is it possible that multiskilling can be both a de-skilling and re-skilling depending on the settings in each newsroom and in different media systems?

This paper is based on a survey conducted in 2012 among 1,500 journalists in Sweden, Poland and Russia, as well as on qualitative interviews with journalists in these three countries. The research questions are the following:

- What are the experiences of and attitudes among journalists with regard to the concept of multiskilling?

- What kind of factors can explain the differences in experience and attitudes age, gender, education and type of media organization?

- How is multiskilling related to downsizing in the newsrooms and demands on increased production?

- How is multiskilling related to perceived autonomy - does it offer more or less power to the journalists?

- What kind of differences are there between media systems and what factors in the media systems can explain these differences?

- How is the journalistic culture changing in multiskilled newsrooms? In the way journalists think about their daily work? 


\section{A survey of 1,500 journalists}

The survey is part of the research project Journalism in change - professional journalistic cultures in Poland, Russia and Sweden. As part of this project, researchers at three universities - Södertörn University in Stockholm, Moscow State University in Russia and University of Wroclaw in Poland - cooperated to study how the professional journalistic culture in each of the three countries has been influenced by media development (Nygren et al, 2012).

The survey was conducted during the spring and summer of 2012. It was organized and carried out by teams in each of the three countries. There are no registers of journalists in these countries and therefore it was not possible to create a random sample of the population. Instead, quota sampling was used to select participants for the survey in order to build a sample that was as representative as possible for journalists in each country (Lavrakas, 2008). Drawing on previous knowledge about the media structure and where journalists work, a quota of journalists was decided for each media type with the goal of collecting 500 surveys in each country. Surveys were sent to a wide range of newsrooms in different parts of the country and different types of media, both on paper (mostly Sweden and Poland) and by email with links to a web-based survey (mostly Poland and Russia). When the quota for each media type was filled, the survey was stopped. The results show that the sample became quite close to other recent surveys (such as Weaver \& Willnat, 2012) (table 1).

The project also includes in-depth interviews with 60 journalists, 20 from each country. The journalists for the interviews were chosen to give broad representation, both in age and from different media types. The interviews lasted for approximately one hour and were transcribed and translated for the group of researchers. More details about the methods are available in a special report from

Table 1: The sample in the Journalism in change survey, 2012 (\%)

\begin{tabular}{lrrrr} 
& Poland & Russia & Sweden & Total \\
\hline Male & 58 & 38 & 47 & 48 \\
Female & 42 & 62 & 53 & 52 \\
& & & & \\
$\leq 35$ years & 42 & 69 & 27 & 47 \\
$36-50$ years & 39 & 23 & 36 & 33 \\
$\geq 51$ years & 18 & 7 & 38 & 21 \\
& & & & \\
Printed paid newspapers & 26 & 35 & 42 & 34 \\
Magazines & 25 & 29 & 13 & 22 \\
Public service/state radio and TV & 22 & 10 & 16 & 16 \\
Commercial-free media* & 25 & 21 & 12 & 19 \\
Subcontractors** & 3 & 6 & 17 & 8 \\
\hline Total number of surveys & 497 & 500 & 500 &
\end{tabular}


the project (Anikina, Dobek-Ostrowska, Nygren, 2013).

In the project the notion of "multiskilling" has been defined from a technological perspective, as the ability to handle different parts of the work process (e.g., reporting, photo, editing, etc.) and to work for different platforms. Multiskilling can also be defined differently; it can be understood from the perspective of content. Interviews with Polish journalists in this project show that they have a broader understanding of this term and include in their understanding of "multiskilling" the ability to cover different areas. This means that even if the questions in the survey are identical and the notion is defined in the question, respondents can interpret statements differently. It is important to have this in mind when comparing levels in the three different countries.

\section{Experience and attitudes}

One question in the survey contained six statements about multiskilling. The journalists had to say whether or not they agreed with those statements (table 2).

Table 2: "Multiskilling" or "multi-reporter" are some words often used to describe future journalists. This can mean both a journalist working in different channels and a journalist working with different parts of the process (photo-writing-editing). What is your opinion on the following statements? (On a scale 1-5, where 1 is Disagree and 5 is Fully Agree. Percent)

\begin{tabular}{|c|c|c|c|c|c|c|c|}
\hline & 1 & 2 & 3 & 4 & 5 & Balance* & $\begin{array}{l}\text { Don't } \\
\text { know/ } \\
\text { missing }\end{array}$ \\
\hline $\begin{array}{l}\text { Ifeel like a multi-skilled } \\
\text { reporter }\end{array}$ & 16 & 12 & 19 & 23 & 25 & +20 & 6 \\
\hline $\begin{array}{l}\text { Journalists in my media } \\
\text { organization are expected to } \\
\text { be multiskilled }\end{array}$ & 7 & 13 & 19 & 28 & 30 & +38 & 4 \\
\hline $\begin{array}{l}\text { In the future more } \\
\text { journalists will be } \\
\text { multiskilled }\end{array}$ & 4 & 5 & 12 & 31 & 42 & +64 & 7 \\
\hline $\begin{array}{l}\text { Multiskilling means more } \\
\text { room for creativity }\end{array}$ & 10 & 14 & 22 & 23 & 28 & +27 & 4 \\
\hline $\begin{array}{l}\text { Multiskilling will decrease } \\
\text { the quality of journalism }\end{array}$ & 15 & 21 & 24 & 18 & 16 & -2 & 6 \\
\hline $\begin{array}{l}\text { Multiskilling gives more } \\
\text { power to the individual } \\
\text { journalist }\end{array}$ & 9 & 16 & 23 & 25 & 22 & +22 & 6 \\
\hline
\end{tabular}


Nearly half agreed with the statement that they feel like a multiskilled reporter. A larger share agreed that journalists in their media organization are expected to be multiskilled (58\%), and even a larger share agreed that more journalists will be multiskilled in the future $(73 \%)$. This shows a gap between the experience of the individual journalist and the expectations of the organization and of the future. Even if journalists in general feel that they are quite multiskilled, the expectations are still higher.

Attitudes toward multiskilling are positive. About half of all journalists in the survey agreed that multiskilling means more room for creativity and more power to the individual journalist. In terms of quality, though, the attitudes are more divided: $34 \%$ agreed that multiskilling will decrease the quality in journalism and $36 \%$ disagreed. The journalists are not convinced that multiskilling is always

Table 3: Correlations between experience and attitudes towards multiskilling (Only significant correlations are given)

\begin{tabular}{|c|c|c|c|c|c|}
\hline & $\begin{array}{l}\text { I feel like a } \\
\text { multiskilled } \\
\text { reporter }\end{array}$ & $\begin{array}{c}\text { Journalists } \\
\text { are } \\
\text { expected... }\end{array}$ & $\begin{array}{l}\text { More room } \\
\text { for } \\
\text { creativity... }\end{array}$ & $\begin{array}{l}\text { Lower } \\
\text { quality }\end{array}$ & $\begin{array}{c}\text { More power } \\
\text { to } \\
\text { journalist... }\end{array}$ \\
\hline \multirow{3}{*}{$\begin{array}{l}\text { I feel like a } \\
\text { multi-skilled } \\
\text { reporter }\end{array}$} & 1 & $0.546^{* *}$ & $0.446^{* *}$ & - & $0.351 * *$ \\
\hline & $\mathrm{N}=1414$ & $\mathrm{~N}=1382$ & $\mathrm{~N}=1374$ & $0.119 * *$ & $\mathrm{~N}=1344$ \\
\hline & & & & $\mathrm{N}=1343$ & \\
\hline \multirow{5}{*}{$\begin{array}{l}\text { Journalists in } \\
\text { my media } \\
\text { organization } \\
\text { are expected to } \\
\text { be multiskilled }\end{array}$} & $0.546^{* *}$ & 1 & $0.339 * *$ & - & $0.227 * *$ \\
\hline & $\mathrm{N}=1382$ & & $\mathrm{~N}=1402$ & & $\mathrm{~N}=1375$ \\
\hline & & & & & \\
\hline & & & & & \\
\hline & & & & & \\
\hline \multirow{4}{*}{$\begin{array}{l}\text { Multiskilling } \\
\text { means more } \\
\text { room for } \\
\text { creativity }\end{array}$} & $0.446^{* *}$ & $0.339 * *$ & 1 & - & $0.613 * *$ \\
\hline & $\mathrm{N}=1374$ & $\mathrm{~N}=1402$ & & $0.112 * *$ & $N=1386$ \\
\hline & & & & $\mathrm{N}=1380$ & \\
\hline & & & & & \\
\hline \multirow{4}{*}{$\begin{array}{l}\text { Multiskilling } \\
\text { decrease the } \\
\text { quality of } \\
\text { journalism }\end{array}$} & $-0.119 * *$ & - & $-0.112 * *$ & 1 & - \\
\hline & $\mathrm{N}=1343$ & & $\mathrm{~N}=1380$ & & \\
\hline & & & & & \\
\hline & & & & & \\
\hline \multirow{5}{*}{$\begin{array}{l}\text { Multiskilling } \\
\text { gives more } \\
\text { power to the } \\
\text { individual } \\
\text { journalist }\end{array}$} & $0.351 * *$ & $0.227 * *$ & $0.613^{* *}$ & - & 1 \\
\hline & $\mathrm{N}=1344$ & $\mathrm{~N}=1375$ & $\mathrm{~N}=1386$ & & \\
\hline & & & & & \\
\hline & & & & & \\
\hline & & & & & \\
\hline
\end{tabular}


good for quality.

An analysis of the correlation between the statements gives some interesting patterns (table 3 ). It shows a strong correlation between the feeling of being a multiskilled reporter and the positive statements about creativity and power; those who have the experience also think it is good for creativity and that it gives them more power in their work. This is not to say that multiskilling (new tools and new tasks in the work) produces creativity: it can also be the other way around, as journalists more interested in testing new forms of creative expression can more likely be positive towards multiskilling and testing new tools. Either way, there is some sort of connection between an openness towards new work practices, creativity and power in the daily work.

There is, however, a clear negative correlation to the statement about lower quality. Those with experience disagreed to a greater extent than journalists in general with the statement that multiskilling results in lower quality. These correlations show that the negative attitudes towards multiskilling (lower quality) are more common among journalists who do not identify themselves as multiskilled. Some of these journalists might be part of the group that feels there is a demand to be multiskilled, but does not identify itself as multiskilled.

\section{Age, gender and education?}

There are clear differences between age groups in experience in and attitudes towards multiskilling (table 4). The number of journalists who feel that they are multi-reporters is much larger among young journalists. The younger groups also have a more positive attitude and agree that multiskilling gives room for creativity and more power to the individual journalist. When it comes to effects on quality, however, the attitudes are quite equal in all age groups. The opinions about quality are divided among all journalists.

Gender has no influence on multiskilling according to the survey. The gender structure is quite different in the three countries. In Poland, journalism is mostly a male-dominated profession; in Russia, it is more female-dominated; and in

Table 4: Experience and attitudes towards multiskilling in different ages (Balance measure $=$ the shares saying agree minus those saying disagree)

\begin{tabular}{|c|c|c|c|c|c|c|}
\hline & -29 & $30-39$ & $40-49$ & $50-59$ & $60-$ & Total \\
\hline Ifeel like a multi-skilled reporter & +32 & +27 & +12 & +9 & -15 & +20 \\
\hline $\begin{array}{l}\text { Multiskilling means more room for } \\
\text { creativity }\end{array}$ & +43 & +26 & +23 & +31 & -6 & +29 \\
\hline $\begin{array}{l}\text { Multiskilling will decrease the } \\
\text { quality of journalism }\end{array}$ & 0 & -5 & -8 & -6 & +11 & -2 \\
\hline $\begin{array}{l}\text { Multiskilling gives more power to } \\
\text { the individual journalist }\end{array}$ & +36 & +20 & +21 & +14 & +6 & +22 \\
\hline $\mathrm{N}=$ & 398 & 408 & 261 & 200 & 90 & 1357 \\
\hline
\end{tabular}


Sweden, the gender breakdown is equal in the total group of journalists. Generally, in all three countries, the share of female journalists is larger in the younger generation. Following the age factor, the attitudes towards multiskilling could be more positive among women, but analysis show equal figures in relation to gender in all age groups.

The analysis shows that education also does not have an influence on multiskilling in general, but at the same time the share of journalists with a professional academic education in journalism is much higher among younger journalists. This means that age and education follow the same patterns.

\section{Media type and media cultures}

The place of work is important for experience and attitudes towards multiskilling (table 5). The journalists in the survey has been categorized based on the "legacyplatform" of their media company. Nearly all media outlets today also have some kind on online presence, and in Sweden newspapers today define themselves as "media houses" publishing in different channels (Nygren \& Zuiderveld, 2011). But still, the legacy of the journalistic culture within the media company plays a role in attitudes towards multiskilling, according to the results.

Journalists in TV and radio more often regard themselves as multi-reporters

Table 5: Experience and attitudes towards multiskilling in different types of media

(Balance measure $=$ those who agreed minus those who disagreed)

\begin{tabular}{|c|c|c|c|c|c|c|}
\hline & Newspaper & Magazine & $T V$ & Radio & News agency & Other* \\
\hline $\begin{array}{l}\text { Ifeel like a multi- } \\
\text { skilled reporter }\end{array}$ & +12 & +16 & +34 & +36 & 0 & +31 \\
\hline $\begin{array}{l}\text { Multiskilling } \\
\text { means more room } \\
\text { for creativity }\end{array}$ & +21 & +28 & +40 & +43 & +22 & +29 \\
\hline $\begin{array}{l}\text { Multiskilling will } \\
\text { decrease the } \\
\text { quality of } \\
\text { journalism }\end{array}$ & -3 & -11 & -5 & +3 & +21 & +10 \\
\hline $\begin{array}{l}\text { Multiskilling } \\
\text { gives more power } \\
\text { to the individual } \\
\text { journalist }\end{array}$ & +14 & +21 & +38 & +39 & +17 & +18 \\
\hline $\mathrm{N}=$ & 524 & 334 & 238 & 157 & 36 & 122 \\
\hline
\end{tabular}


than their colleagues in print. Also, the positive attitudes are much stronger in radio and TV. One explanation for this can be that radio and TV have always had newsrooms with a strong presence of technology. For journalists in these platforms it has not been so strange to change the division of labor and take over parts of the work that had been previously carried out by technicians. In newspapers, there has been an established separation between the work of reporters and photographers, subeditors, typesetters and printers, at least in Sweden (Alström, 2008).

When it comes to the question about what multiskilling means for quality, the attitudes are divided as earlier. Journalists in radio and TV are as critical as their colleagues in newspapers, although the most critical are journalists at news agencies.

Also, the size of the newsroom matters when it comes to multiskilling (table 6). Journalists working in small newsrooms identify themselves as multi-reporters to a much larger extent than journalists in large newsrooms. They are also more positive, with one exception: journalists working in newsrooms with over 100 journalists are more positive than journalists in medium-sized newsrooms. Even if they do not feel themselves to be multi-reporters, they are more positive when it comes to creativity and power. As earlier, the question about quality showed no clear pattern - those in medium-sized newsrooms are more likely to agree that multiskilling decreases quality.

It seems that organization and culture in the workplace are important for multiskilling. In small newsrooms there are clear advantages to being multiskilled, and in newsrooms with strong technical tradition (radio/TV), multiskilling is more frequent than in newspapers where technical production

Table 6: Experience and attitudes towards multiskilling in newsrooms of different sizes (number of journalists in the newsroom)

(Balance measure $=$ those who agree minus those who disagree)

\begin{tabular}{|c|c|c|c|c|c|c|}
\hline & $1-9$ & $10-24$ & $25-49$ & $50-99$ & 100 & $P=$ \\
\hline $\begin{array}{l}\text { Ifeel like a multi-skilled } \\
\text { reporter }\end{array}$ & +38 & +31 & +11 & +6 & -4 & $-0.189 * *$ \\
\hline $\begin{array}{l}\text { Journalists in my media } \\
\text { organization are expected to } \\
\text { be multiskilled }\end{array}$ & +49 & +47 & +26 & +33 & +30 & $-0.105^{* *}$ \\
\hline $\begin{array}{l}\text { Multiskilling means more } \\
\text { room for creativity }\end{array}$ & +50 & +39 & +12 & +8 & +30 & $-0.166^{* *}$ \\
\hline $\begin{array}{l}\text { Multiskilling will decrease } \\
\text { the quality of journalism }\end{array}$ & -8 & -16 & -3 & +13 & -4 & - \\
\hline $\begin{array}{l}\text { Multiskilling gives more } \\
\text { power to the individual } \\
\text { journalist }\end{array}$ & +46 & +24 & +19 & +3 & +16 & $-0.165 * *$ \\
\hline $\mathrm{N}=$ & 248 & 202 & 224 & 198 & 179 & \\
\hline
\end{tabular}


have been handled in other departments. The radio and TV newsrooms are also often quite small. In medium-sized newspaper organizations the level of experience is lower and attitudes less positive. The division of labor is still strong, i.e., there is more specialization in these newsrooms.

A common assumption is that there is a relationship between the reduction in the size of a newsroom and multiskilling. In a general sense this might be correct, since the presence of fewer resources means that journalists have to do larger parts of the work process (some examples are presented in the interviews below). However, the survey showed no correlation between these factors. In the survey, $53 \%$ of the journalists say the staffing in their newsroom has decreased in the last five years and only $18 \%$ say that it has increased. The share saying that they are expected to be multiskilled, though, is almost equal in both types $-62 \%$ in newsrooms where staff has been downsized and 69\% in newsrooms where the staff has been increasing. This means multiskilling is not primarily a way to downsize the newsroom, but an industry norm for organizing work in newsrooms of today in general.

\section{Change in the work}

Multiskilling is one of the changes in daily journalistic work. In another question in the survey, the journalists assessed how much more or less time they spent on different parts of the work process compared with 5-10 years ago (table 7). This is an estimate and thus not a clear measure; it only gives an estimation based on the feelings and experience of the journalists. The results show different patterns:

In Sweden, journalists spend more time doing work connected directly to production, such as writing and editing. They spend less time on other parts of the process, like work outside the newsroom and evaluation/discussion. The time for research is almost the same.

In Poland, journalists are doing more of everything. At the top is editing/layout and photography, parts of the process that are connected to multiskilling. They also spend more time on contact with the audience and research.

In Russia, the pattern is the same as in Poland except when it comes to cooperation in the newsroom, which is on the same level.

These results show multiskilling from another perspective: the parts of the work process that are connected directly to production have increased everywhere and journalists are doing more work that had been previously done by others (photographers and technicians).

There are also some clear correlations between changes in the work and multiskilling. In newsrooms where journalists are expected to be multiskilled, journalists also report spending more time on the parts of the working process connected directly to production - writing/producing, photography and 
Table 7: "During the last 5-10 years daily journalistic work has changed in many ways. How would you rate these changes in different areas, according to your own experience?" Answers given on a scale from 1-5, where 1 is much less and 5 is much more. The figures are a balance, i.e. the share answering "more" minus the share answering "less".

\begin{tabular}{lrrr} 
& Poland & Russia & Sweden \\
\hline Research and verification & +37 & +28 & -2 \\
Work outside the newsroom & +15 & +32 & -26 \\
Writing/producing & +36 & +38 & +39 \\
Editing/layout & +65 & +61 & +32 \\
Contact with the audience & +39 & +48 & +13 \\
Cooperation in the newsroom & +24 & +4 & +22 \\
The amount of production & +23 & +23 & +66 \\
Evaluation and discussion & +5 & +29 & -17 \\
Photography & +43 & +47 & +23 \\
\hline N=* & $369-441$ & $350-409$ & $326-380$
\end{tabular}

* Only those with 5-10 years of experience could answer the question. The range of $\mathrm{N}$ means the numbers of answers differs for each question.

editing/layout. They also report an increasing amount of production in the last 510 years.

This correlation is especially clear in Sweden $-37 \%$ of the journalists in newsrooms where the amount of production has increased a lot also report that they are expected to be multiskilled. The same figure in newsrooms with the same level of production is $17 \%$ (corr. $\mathrm{R}=0.228$, sign. 0.001 level).

This difference is also clear in Russia. The figures for expectations on multiskilling are $45 \%$ in newsrooms with a large increase in production and $18 \%$ in newsrooms with the same production $(\mathrm{R}=0.143$, sign. 0.01 level). In Poland there is no clear correlation.

A common pattern is visible in an analysis of the correlation between demands in production and expectations on multiskilling: there are a strong correlation between more writing, photography, editing and multiskilling (table 8). There are also some concerns about quality in journalism and time for writing/producing. Those who report more time spent on writing/producing are also more concerned about decreased quality due to multiskilling.

Other research has reported a large degree of recycling of content; the same content is used for different channels in 24/7 news work (Boczkowski, 2010). Recycling is necessary to fill the different channels with content, and multiskilling is one of the strategies to manage this with the same staff (or less). The results from the survey and the interviews show multiskilling is part of the new standard in the media industry in order to make it possible to maintain news production. Multiskilling is also necessary for many small newsrooms with limited resources if they want to compete in times of hard economic pressure. 
Table 8: Correlations between multiskilling and increased production in newsrooms in the last 5-10 years (as perceived by journalists)

\begin{tabular}{|c|c|c|c|c|c|c|}
\hline & $\begin{array}{l}\text { Journa- } \\
\text { lists are } \\
\text { expected } \\
\text { to be } \\
\text { multi- } \\
\text { skilled }\end{array}$ & $\begin{array}{l}\text { Multi- } \\
\text { skilling } \\
\text { gives } \\
\text { lower } \\
\text { quality } \\
\text {... }\end{array}$ & $\begin{array}{l}\text { Time for } \\
\text { writing } \\
\& \\
\text { produc- } \\
\text { tion }\end{array}$ & $\begin{array}{l}\text { Time for } \\
\text { editing } \\
\& \\
\text { layout }\end{array}$ & $\begin{array}{l}\text { Level of } \\
\text { production }\end{array}$ & $\begin{array}{l}\text { Time for } \\
\text { photo }\end{array}$ \\
\hline $\begin{array}{l}\text { Journalists } \\
\text { expected to } \\
\text { be } \\
\text { multiskilled }\end{array}$ & $\begin{array}{l}1 \\
N=1443\end{array}$ & - & $\begin{array}{l}0.750^{*} \\
\mathrm{~N}=1168\end{array}$ & $\begin{array}{l}0.590 * \\
\mathrm{~N}=1111\end{array}$ & $\begin{array}{l}0.940 * * \\
\mathrm{~N}=1098\end{array}$ & $\begin{array}{l}0.129 * * \\
\mathrm{~N}=1026\end{array}$ \\
\hline $\begin{array}{l}\text { Multiskilling } \\
\text { gives lower } \\
\text { quality... }\end{array}$ & - & $\begin{array}{l}1 \\
N=1408\end{array}$ & $\begin{array}{l}0.144 * * \\
\mathrm{~N}=1150\end{array}$ & - & $\begin{array}{l}0.126^{* *} \\
\mathrm{~N}=1074\end{array}$ & $\begin{array}{l}0.70 * \\
\mathrm{~N}=1009\end{array}$ \\
\hline $\begin{array}{l}\text { Time for } \\
\text { writing \& } \\
\text { production }\end{array}$ & $\begin{array}{l}0.75^{*} \\
\mathrm{~N}=1168\end{array}$ & $\begin{array}{l}0.144 * * \\
\mathrm{~N}=1150\end{array}$ & $\begin{array}{l}1 \\
N=1198\end{array}$ & $\begin{array}{l}0.435^{* *} \\
\mathrm{~N}=1110\end{array}$ & $\begin{array}{l}0.364 * * \\
\mathrm{~N}=1086\end{array}$ & $\begin{array}{l}0.254^{* *} \\
\mathrm{~N}=1016\end{array}$ \\
\hline $\begin{array}{l}\text { Time for } \\
\text { editing \& } \\
\text { layout }\end{array}$ & $\begin{array}{l}0.59 * \\
\mathrm{~N}=1111\end{array}$ & - & $\begin{array}{l}0.435^{* *} \\
\mathrm{~N}=1110\end{array}$ & $\begin{array}{l}1 \\
N=1138\end{array}$ & $\begin{array}{l}0.260^{* *} \\
\mathrm{~N}=1037\end{array}$ & $\begin{array}{l}0.412 * * \\
\mathrm{~N}=983\end{array}$ \\
\hline $\begin{array}{l}\text { The level of } \\
\text { production }\end{array}$ & $\begin{array}{l}0.94 * * \\
\mathrm{~N}=1098\end{array}$ & $\begin{array}{l}0.126 * * \\
\mathrm{~N}=1074\end{array}$ & $\begin{array}{l}0.364 * * \\
\mathrm{~N}=1086\end{array}$ & $\begin{array}{l}0.260^{* *} \\
\mathrm{~N}=1037\end{array}$ & $\begin{array}{l}1 \\
N=1120\end{array}$ & $\begin{array}{l}0.260 * * \\
\mathrm{~N}=959\end{array}$ \\
\hline $\begin{array}{l}\text { Time for } \\
\text { photo }\end{array}$ & $\begin{array}{l}0.129 * * \\
\mathrm{~N}=1026\end{array}$ & $\begin{array}{l}0.70^{*} \\
\mathrm{~N}=1009\end{array}$ & $\begin{array}{l}0.254^{* *} \\
\mathrm{~N}=1016\end{array}$ & $\begin{array}{l}0.412 * * \\
\mathrm{~N}=983\end{array}$ & $\begin{array}{l}0.260^{* *} \\
\mathrm{~N}=959\end{array}$ & $\begin{array}{l}1 \\
N=1045\end{array}$ \\
\hline
\end{tabular}

\section{Multiskilling and perceived autonomy}

Some kind of autonomy in the daily work is an important part of the professional identity for journalists in all kinds of media systems. In one question in the survey journalists say that freedom in their work is the second most important factor in choosing their place of work (Anikina, Dobek-Ostrowska, Nygren, 2013). Other research has also found a clear connection between job satisfaction and the level of autonomy in daily work (Weaver \& Willnat, 2012). 
Table 9: Perceived autonomy in daily work in Poland, Russia and Sweden (\%)

\begin{tabular}{llll} 
& Poland & Russia & Sweden \\
\hline Almost always can get a subject covered & 59 & 42 & 45 \\
Almost complete freedom in selecting stories & 31 & 25 & 31 \\
Almost complete freedom in deciding emphasis & 30 & 30 & 30 \\
\hline$N=$ & 490 & 487 & 473
\end{tabular}

There is a number of questions in the survey to measure the level of perceived autonomy among journalists in the three countries. The results (table 9) are very similar. The feeling of autonomy in daily work is almost exactly the same among journalists in Sweden and Russia, and a little bit higher in Poland, when it comes to the ability to get a subject covered. In other questions on the estimated level of press freedom in the country, there are major differences between the countries. Nearly every second Russian journalist says that freedom of the press has declined in the last five years (Anikina, Dobek-Ostrowska, Nygren, 2013). When it comes to daily work, however, a certain level of perceived autonomy seems to be part of the professional identity, a level of freedom given within the framework of the media system.

The analysis shows that there are clear correlations in the survey between perceived autonomy and attitudes towards multiskilling. Journalists who say that they feel like a multi-reporter also say that they have a greater degree of freedom in their work (table 10). They believe that they can get subjects covered, choose stories and decide on the angle to a greater extent than journalists who are not multiskilled. Journalists who agreed that multiskilling makes journalism more creative and puts more power in the hands of the individual journalist also report a higher level of perceived autonomy. The pattern is clear in all countries, but it is stronger in Russia ( $\mathrm{R}=0.18-0.21$, sign. 0.01 level).

When analyzing perceived autonomy in general, the degree of autonomy grows with age. Older journalists feel that they have more freedom in their daily work in terms of choice of subjects and angles. When analyzing multiskilling, the age factor works the other way; younger journalists feel much more like multireporters (table 4). In spite of this, multiskilled journalists feel themselves to have more autonomy in their daily work than other colleagues. Among those who view themselves as multiskilled, 57\% say that they almost always can get a subject covered. The figure among those not describing themselves as multiskilled is $38 \%$. It seems that multiskilling is a stronger positive factor for perceived autonomy than age.

\section{Differences among media systems}

The patterns are the same in all three countries in terms of experiences and attitudes towards multiskilling, but there are clear differences in how the 
statements are rated (table 11). In Poland, all of the statements are rated high with the exception of the negative attitude on quality. A mean of 3.9 for experience means that $66 \%$ of the Polish journalists agreed that they feel like a multiskilled reporter. The spread in attitudes is also quite small, with the exception of the consequences for quality. Nearly one out of three agreed that multiskilling decreases quality in journalism.

In Russia, the pattern is the same but the figures are generally lower. There are also larger differences among journalists when it comes to the future. Only about half of the journalists are convinced that more journalists will be multiskilled in the future. In Sweden, the attitudes towards multiskilling are mostly negative. The shared thinking that quality will decrease is larger than the group with a positive attitude (more room for creativity and more power). There is also a larger spread among journalists when it comes to experience; nearly one-

Table 10: Correlation between attitudes towards multiskilling and perceived autonomy

\begin{tabular}{|c|c|c|c|}
\hline & $\begin{array}{l}\text { How often are } \\
\text { you able to get a } \\
\text { subject covered? }\end{array}$ & $\begin{array}{l}\text { How much } \\
\text { freedom do you } \\
\text { have in selecting } \\
\text { stories? }\end{array}$ & $\begin{array}{l}\text { How much freedom } \\
\text { do you have to } \\
\text { decide emphasis in } \\
\text { stories? }\end{array}$ \\
\hline $\begin{array}{l}\text { I feel like a multi-skilled } \\
\text { reporter }\end{array}$ & $\begin{array}{l}0.176^{* *} \\
\mathrm{n}=1373\end{array}$ & $\begin{array}{l}0.168^{* *} \\
\mathrm{n}=1385\end{array}$ & $\begin{array}{l}0.112^{* *} \\
\mathrm{n}=1381\end{array}$ \\
\hline $\begin{array}{l}\text { Journalists in my media } \\
\text { organization are } \\
\text { expected to be } \\
\text { multiskilled }\end{array}$ & $\begin{array}{l}0.212 * * \\
\mathrm{n}=1401\end{array}$ & $\begin{array}{l}0.122 * * \\
\mathrm{n}=1410\end{array}$ & $\begin{array}{l}0.097 * * \\
\mathrm{n}=1407\end{array}$ \\
\hline $\begin{array}{l}\text { Multiskilling means } \\
\text { more room for } \\
\text { creativity }\end{array}$ & $\begin{array}{l}0.157 * * \\
\mathrm{n}=1393\end{array}$ & $\begin{array}{l}0.119 * * \\
\mathrm{n}=1403\end{array}$ & $\begin{array}{l}0.112 * * \\
\mathrm{n}=1399\end{array}$ \\
\hline $\begin{array}{l}\text { Multiskilling will } \\
\text { decrease the quality of } \\
\text { journalism }\end{array}$ & - & - & - \\
\hline $\begin{array}{l}\text { Multiskilling gives more } \\
\text { power to the individual } \\
\text { journalist }\end{array}$ & $\begin{array}{l}0.108 * * \\
\mathrm{n}=1371\end{array}$ & $\begin{array}{l}0.101 * * \\
\mathrm{n}=1379\end{array}$ & $\begin{array}{l}0.063^{*} \\
\mathrm{n}=1374\end{array}$ \\
\hline $\begin{array}{l}\text { ** Correlation is signific } \\
* \text { Correlation is significa } \\
\text { (Pearson correlation, onl }\end{array}$ & $\begin{array}{l}t \text { at the } 0.01 \text { level } \\
\text { at the } 0.05 \text { level ( } \\
\text { ignificant correla }\end{array}$ & $\begin{array}{l}\text {-tailed) } \\
\text { tailed) } \\
\text { ns are given) }\end{array}$ & \\
\hline
\end{tabular}


third of the journalists disagreed completely with the statement that they feel like a multiskilled reporter.

These differences can be explained by differences in the media systems and in the profession. Some differences are also connected to how the notion of "multiskilling" is understood by journalists (see the paragraph on methods).

Age is an important factor. The profession is much older in Sweden than in Poland and Russia (table 1). In Sweden, 38\% of the journalists in the sample are older than 50, compared with 18\% in Poland and 7\% in Russia. Age is important for experience and attitudes (table 4), and this can explain part of the differences between the countries.

Media structure is another important factor. In Poland and Russia, the share working in radio, TV and commercial free media (for example online) is larger than in Sweden, which has a large sector of printed paid newspapers. In analyses of multiskilling in different types of media, printed newspapers are lagging behind the transition, according to the results from the survey.

The degree of complaints about working conditions is clearly higher in Sweden than in Poland and Russia. In other questions, compared to their colleagues in Poland and Russia, Swedish journalists say they have less freedom to manage their own time. They also consider an increasing work rate to be a threat to their independence (Nygren \& Appelberg, 2013). With more pressure to produce, it is not difficult to see that new digital tools for production can develop negative attitudes.

As mentioned earlier, many Polish journalists seem to have a broader definition of multiskilling, including also the ability to cover different areas and subjects. This can explain some of the more frequent multiskilling in Poland.

Table 11: Experience and attitudes towards multiskilling in three countries. Mean on a scale of $1-5$, where 1 is disagree and 5 is fully agree, std. = standard deviation.

\begin{tabular}{|c|c|c|c|c|c|c|}
\hline & \multicolumn{2}{|c|}{ Poland } & \multicolumn{2}{|c|}{ Russia } & \multicolumn{2}{|c|}{ Sweden } \\
\hline & Mean & Std & Mean & Std & Mean & Std \\
\hline I feel like a multi-skilled reporter & 3.9 & 1.18 & 3.2 & 1.31 & 2.8 & 1.53 \\
\hline $\begin{array}{l}\text { Journalists in my media } \\
\text { organization are expected to be } \\
\text { multiskilled }\end{array}$ & 4.2 & 0.97 & 3.3 & 1.29 & 3.4 & 1.28 \\
\hline $\begin{array}{l}\text { Multiskilling means more room } \\
\text { for creativity }\end{array}$ & 3.8 & 1.17 & 3.6 & 1.34 & 3.0 & 1.27 \\
\hline $\begin{array}{l}\text { Multiskilling will decrease the } \\
\text { quality of journalism }\end{array}$ & 2.8 & 1.29 & 3.0 & 1.30 & 3.1 & 1.33 \\
\hline $\begin{array}{l}\text { Multiskilling gives more power to } \\
\text { the individual journalist }\end{array}$ & 3.7 & 1.12 & 3.6 & 1.21 & 2.9 & 1.24 \\
\hline $\begin{array}{l}\text { In the future more journalists will } \\
\text { be multiskilled }\end{array}$ & 4.4 & 0.82 & 3.5 & 1.3 & 4.4 & 0.8 \\
\hline $\mathrm{N}=$ & 45 & & & & & \\
\hline
\end{tabular}




\section{More critical responses in the interviews}

In the interviews with 20 journalists in each country, the experience and attitudes towards multiskilling become more complex than in the survey. The journalists paint a more critical picture of multiskilling in their daily work and the effects on quality.

Many of the journalists view multiskilling as a way to increase efficiency in the media companies. Some journalists say that multiskilling is necessary from a financial point of view, but that it also decreases their influence on quality. A young Polish radio reporter describes it like this:

Multiskilling is unfortunately unavoidable because this way work is done more quickly and the cost is reduced. But of course it is clear that the quality is adversely affected...if you have three different things to do, you cannot concentrate on one of them and do it well... (PR16 $\left.6^{1}\right)$

In small newsrooms, journalists consider multiskilling to be necessary and natural. A Swedish TV reporter in regional news describes the advantage of multiskilling as not being so locked into different roles, enabling journalists to work together in new ways. The disadvantage is that the newsroom does not get more resources:

This means it takes longer to produce the piece. You have to do the research, take pictures, write for the web. Downsizing the newsroom means lower quality when producing more. But there is an acceptance for lower quality in the filming today. (SR5)

The Russian journalists also say that there is a risk of lower quality if everybody has to do everything in the process. They emphasize more often the collaboration between journalists and other professionals such as photographers. One print journalist describes the work as a "team sport" where the journalists have to trust colleagues with other specializations (RR16). Another journalist says that negative effects of multi-functionality can only appear when a journalist tries to substitute other employees:

The advantage of a multifunctional journalist is the ability to work together with other colleagues. This is not to say that the camera operator or the cutter or other employees are unnecessary. (RR14)

Many journalists from all three countries describe this conflict between efficiency and quality and how it is impossible to be equally skillful in all parts of the work at the same time. Some of them, though, also see advantages other than just the

\footnotetext{
${ }^{1}$ Polish respondent $\mathrm{nr} 16 . \mathrm{SR}=$ Swedish respondent and $\mathrm{RR}=\mathrm{Russian}$ Respondent.
} 
financial benefits, for example controlling the whole process can give the individual journalist more power in his or her daily work. A Polish freelancer says multiskilling has eliminated the feeling that she is just a cog in a machine: "you can have endless possibilities" (PR16). A Swedish TV reporter describes it like this:

Everybody who has worked in teams knows that when working with a photographer you have to negotiate about the picture that needs to be taken. As a video reporter, you decide yourself what kind of tone you will have in the piece. The disadvantage is that you lose the expert part. You are perhaps not at your best at journalism, photography, editing or research when you have to share all your time between everything. (SR9)

A Russian producer on the commercial TV channel, Dozhd, declared that the channel is well known for its structure where all journalists do everything. They have a rotation between different roles in the production:

There are definite pros. If something "blows up in our faces" every employee can go on air, arrange an expert search, anchor a show and prepare news independently. The disadvantage of this profession is that the material has to be presented promptly and we often don't have time for in-depth analysis of the material. (RR20)

Some of the journalists emphasize that the technological development does not change the fundamentals of the profession. A Russian editor in a weekly magazine says journalists can be multifunctional, but that each has to do his or her own professional work. (RR15) A Polish editor on a regional newspaper says technology makes production easier and faster, but there is also more work to be done:

The production process has been shortened and this is one thing. It doesn't change the fact, however, that the basic tasks a journalist must carry out are the same now as they were before. (PR10)

In the interviews, most journalists talked about both positive and negative aspects of multiskilling. Many of them consider multiskilling unavoidable; new technology has always changed the profession and daily work and will continue to do so - a kind of technological determinism. But on the other hand, they try to adapt and find the positive possibilities. In the interviews, some of the journalists describe multiskilling as giving them new opportunities. At the same time they worry about quality. Given the financial gains of multiskilling, however, these fears carry little weight. 


\section{Conclusions}

The survey and the interviews paint a complex picture of multiskilling in newsrooms in the three countries. Journalists are divided in their experiences and attitudes, but the analysis shows some clear patterns. From these patterns it is possible to discuss the question of de-skilling or re-skilling of journalism.

- Younger journalists and those working in small newsrooms in radio and TV more often define themselves as multi-reporters. On the other end of the scale we find that older journalists working in medium-sized newspapers much more seldom identify themselves as multi-reporters.

- Those who define themselves as multi-reporters more often have positive attitudes towards multiskilling - they think it gives more room for creativity and more power to the individual journalist. Journalists lacking experience have less positive attitudes.

- There are clear connections between multiskilling and increasing demands in production, but there is no correlation at all between multiskilling and downsizing of newsrooms. Regardless of whether the staff in the newsroom has shrunk or increased, the share saying that multiskilling is expected in the workplace is the same. Multiskilling is a new way of organizing work in all kinds of media, not just those that are downsizing.

- There are fears in all groups about the consequences for quality. Groups without experience of multiskilling express the most fear, but other journalists are also discussing the quality issue.

- There are clear correlations between perceived autonomy and multiskilling. Those who regard themselves as multi-reporters perceive themselves to have more freedom to get a subject covered and select their own stories.

Taken together, these results show no proof of the "de-skilling hypothesis". There are problems concerning quality in newsrooms that are adapting multiskilling strategies, but in general multiskilling is more correctly defined as a re-skilling or an up-skilling. The new division of labor in journalism gives more room for creativity and more power to the individual journalist according to those with experience as multi-reporters. It gives them more room for autonomy in their daily work, but at the same time multiskilling is also a strategy to increase efficiency and production in the newsrooms.

Multiskilling is very much about technological possibilities, but technology itself does not decide the consequences. It becomes more of a question as to how technology is embedded into the social and organizational context in media production (Örnebring, 2010). For journalists, multiskilling can be a means to increase production with the same or fewer resources, but it can also be a tool to increase creativity, gain greater autonomy in daily work and place more of an emphasis on quality. It all depends on how technology is used and organized in the newsrooms. 


\section{Changing professional culture?}

The purpose of the Journalism in change project is to study how professional journalistic cultures are influenced by media development. Multiskilling is one important part of this - changed divisions of labor with new tasks and new tools in the daily work can influence how journalists think about their work. New routines and norms in the newsroom are emerging and the tacit knowledge of the professionals may be slowly changing during this process.

This survey offers no final answers about how the professional culture is changing, but rather presents a starting point for discussion.

Journalists report on less time spent on work outside the newsroom. This is also visible in other research (Lee-Wright \& Philips, 2012). More time is spent on production for different channels and the recycling of content for different formats. The importance of desk-work is growing. Research on online news has shown an increasing imitation in news production. In hard news 24/7 the output becomes more similar, and this production is managed by multiskilled journalists producing for different platforms (Boczkowski, 2010). The focus of journalistic processes on producing without a deadline is shifting from research to publishing, from input to output. This trend is also amplified by the need among media companies to reduce costs for production of content. Having multiskilled journalists producing for many platforms is cost-effective.

At the same time, the survey shows that journalists with multiskilling experience perceive themselves to be more autonomous in their daily work. They feel their broader skills gives them both more room for creativity and more power in their daily work. Journalists who consider themselves to be multiskilled are much more positive - those most critical are older print journalists who are lagging behind.

This might indicate an increasing polarization among journalists:

- Between vanishing "print cultures" and expanding "cross-platform production cultures" that are often connected to TV and radio where multiskilling is the new norm.

- Between younger and older journalists with different patterns of competence.

- Between flexible and multiskilled "production journalists" working at the desk and journalistic "stars" in companies with their own columns and programs.

Multiskilling is influencing the professional culture in journalism in all kinds of media systems and likely enforcing a process of homogenization. Less "shoeleather" reporting and more "desktop reporting" is changing the culture, making journalists more like old-fashioned editors taking care of content coming into the newsroom. They are not so much reporters "in the field" any more but more like editors monitoring social media and news wires and recycling content produced elsewhere in the company. At the same time there are also other possibilities - 
opportunities for a new kind of autonomy for journalists when they can control the whole process and when technology is so cheap that every journalist can have their own tools for production. It also opens more possibilities for an entrepreneurial journalism outside media companies.

How this will change the professional culture among journalists in the future is an area for further research.

\section{References:}

Alström, B. (2008). Från tidningsföretag till marknadsplats för ikoner. In Hvitfelt, H. \& Nygren, G.(ed) På väg mot medievärlden 2020 - journalistik, teknik, marknad. (On the road to Media World 2020 - journalism, technology, market). Lund: Studentlitteratur.

Anikina, M., Dobek-Ostrowska, B., \& Nygren, G. (2013). Journalists in three media systems. Polish, Russian and Swedish journalists about values and ideals, daily practice and the future. Moscow: Faculty of Journalism.

Boczkowski, P. J. (2010). News at Work. Imitation in an Age of Information Abundance. Chicago and London: University of Chicago Press.

Börnfelt, P-O. (2011). Arbetsorganisation i praktiken. (Work organization in practice). Stockholm: SNS Förlag.

Deuze, M. (2007). Media Work. London: Polity Press.

Karlsson, M. (2010). Nätnyheter - från sluten produkt till öppen process. (Online news - from a closed product to an open process). Stockholm: Institutet för mediestudier.

Konow Lund, M. (2013). Moving Image News Production in Two Newsrooms. Oslo: University of Oslo.

Lavrakas P. J. (2008). Encyclopedia of Survey Research Methods. DOI: 10.4135/9781412963947, downloaded 2013/07/21

Lee-Wright, P., Philips, A. (2012). Doing it all in the multiskilled universe. In P. Lee-Wright, A. Philips, \& T. Witschge (Eds.), Changing Journalism (pp. 6380). London and New York: Routledge

Lee-Wright, P., Philips, A., \& Witschge, T. (2012). Changing Journalism. London and New York: Routledge.

Magnusson, L. (2006). Håller den svenska modellen? Arbete och välfärd $i$ en global värld. (Is the Swedish model still valid - work and welfare in a global world). Stockholm: Norstedts.

Mitchelstein, E. \& Boczkowski, P. J. (2009). A review of recent research on online news production, Journalism 10 (5), 562-586.

Nygren, G. (2008). Nyhetsfabriken. Journalistiska yrkesroller i en förändrad medievärld. (The news factory - journalistic professional roles in a changed media world). Lund: Studentlitteratur. 
Nygren, G. \& Zuiderveld, M. (2011). En himla många kanaler-

flerkanalpublicering i svenska mediehus (A lot of channels - cross platform publishing in Swedish media houses). Göteborg: Nordicom.

Nygren, G. (ed.) (2012). Journalism in Russia, Poland and Sweden-traditions, cultures and research. Stockholm: Södertörns University.

Nygren, G. \& Appelberg, J. (2013). Swedish journalists, a profession in decline? In Anikina, M.; Dobek-Ostrowska, B. and Nygren, G. (Eds.), Journalists in three media systems. Polish, Russian and Swedish journalists about values and ideals, daily practice and the future Journalism (pp.115-164). Moscow: Faculty of Journalism.

Opgenhaffen, M., d'Haenens, L. \& Corten, M. (2013). Journalistic tools of the trade in Flanders. Journalism Practice 7 (2), 127-144.

Örnebring, H. (2010). Technology and journalism-as-labour: Historical perspectives. Journalism 11 (1), 57-74.

Örnebring, H. (2013). Anything you can do, I can do better? Professional journalists on citizen journalism in six European countries. International Communication Gazette 75, 35-53.

Ottosen, R. \& Krumsvik, A. H. (2010). Digitisation and Editorial Change in Online Media. Findings from a Norwegian Research Project. Nordicom Information $4 / 2010$.

Quandt, T. \& Singer, J. B. (2009). Convergence and Cross-Platform Content Production. In Wahl-Jörgensen, K. \& Hanitzsch, T. (eds.), The Handbook of Journalism Studies (pp. 130-144). New York and London: Routledge.

Quinn, S. (2005). Convergence's Fundamental Question. Journalism Studies 6 (1), 29-38.

Stiernstedt, F. (2013). Från radiofabrik till mediehus. Medieförändring och medieproduktion på MTG-radio (From a radio factory to a media house. Media change and media production). Örebro: Örebro universitet.

Weaver, D. H. \& Willnat, L. (2012). The Global Journalist in the 21st Century. New York and London: Routledge. 